Siti Aisyah et all, Analisis Finansial

\title{
ANALISIS FINANSIAL DAN SENSITIVITAS USAHA PENGGILINGAN PADI
}

\author{
Siti Aisyah" ${ }^{1}$, Muhammad Hanif Fachrizal ${ }^{2}$ \\ Program Studi Agribisnis Fakultas Pertanian \\ Universitas Swadaya Gunung Jati Cirebon \\ email : ais566474@gmail.com
}

\begin{abstract}
ABSTRAK
Tujuan dari penelitian ini yaitu : (1) untuk mengetahui kelayakan usaha penggilingan padi dan (2) untuk mengetahui seberapa sensitif terhadap beberapa perubahan variabel yang mungkin terjadi yakni penurunan jumlah giling sebesar 10\% dan kenaikan harga BBM (solar) sebesar 5,3\% pada usaha penggilingan padi. Desain penelitian yang digunakan dalam penelitian ini menggunakan metode deskriptif kuantitatif dengan metode penelitian survei. Populasi yang digunakan merupakan pengusaha penggilingan padi di Kecamatan Lemahabang Kabupaten Cirebon yang sesuai dengan kriteria penelitian berjumlah 8 orang. Teknik analisis data mengunakan analisis kelayakan dengan pendekatan analisis investasi yaitu menggunakan NPV (Net Present Value), IRR (Internal Rate of Return), Net B/C Ratio, ARR (Average Rate of Return) dan Payback Period dan analisis sensitivitas perubahan variabel terjadi penurunan jumlah giling 10\% dan kenaikan harga solar 5,3\% Hasil penelitian menunjukan bahwa 1. Usaha penggilingan padi layak untuk dijalankan dengan nilai NPV (Net Present Value) sebesar Rp.21.804.273, IRR (Internal Rate of Return) sebesar 23\%, Net B/C Ratio sebesar 1,18, ARR (Average Rate of Return) sebesar 58\% dan Payback periode selama 3 tahun 6 bulan 7 hari. 2. Analisis sensitivitas dengan penurunan jumlah giling sebesar $10 \%$ mengakibatkan usaha ini tetap layak akan tetapi rawan untuk dijalankan karena mengakibatkan seluruh nilai kriteria analisis mendekati batas kriteria kelayakan dan pada saat penurunan sebesar 15\% menjadi tidak layak, pada saat kenaikan harga solar sebesar 5,3\% usaha ini masih layak untuk dilaksanakan karena dampaknya tidak terlalu berpengaruh secara signifikan.
\end{abstract}

Kata Kunci : Penggilingan Padi, Kelayakan Usaha, Sensitivitas 


\section{PENDAHULUAN}

Kebutuhan beras dalam negeri semakin hari semakin meningkat karena meningkatnya pertumbuhan penduduk Indonesia yang mencapai 252,17 juta orang dengan laju pertumbuhan sebesar $1,31 \%$ dan tingkat konsumsi beras mencapai 132, $98 \mathrm{~kg} / \mathrm{kapita} / \mathrm{tahun}$, sehingga dengan adanya pertambahan penduduk setiap tahun, maka peningkatan produksi beras saat ini menjadi prioritas untuk mengatasi kekurangan suplai (Nuryati, Waryanto, \& Noviati, 2015).

Penanganan pasca panen padi sangat perlu diperhatikan dengan baik dengan menggunakan teknologi yang paling tepat untuk menekan susut mutu dan susut jumlah serta memberikan nilai ekonomi yang optimal. Salah satu unsur penanganan pascapanen padi adalah penggilingan padi yang memperhatikan proses penanganan dan pengolahan. Penggilingan padi memiliki peran yang sangat penting dalam merubah padi menjadi beras yang layak di konsumsi oleh konsumen, proses penggilingan padi sangat penting untuk menjaga kualitas dan menghindari kehilangan signifikan dari hasil budidaya padi.

Salah satu kecamatan yang terdapat usaha penggilingan padi di Jawa Barat adalah di Kecamatan Lemahabang Kabupaten Cirebon, jasa penggilingan padi di Kecamatan Lemahabang tersebar di masing-masing desa, rata-rata di setiap desa terdapat dua sampai 3 unit usaha jasa penggilingan padi. Perlu dilakukan sebuah analisis kelayakan melalui pendekatan finansial apakah bisnis jasa dalam usaha penggilingan padi masih bisa tetap berjalan dan memiliki nilai ekonomi bagi pelaku usaha.

Pada kenyataanya usaha penggilingan padi di lokasi penelitian belum banyak berkembang mengingat usaha tersebut tidak berjalan selama setahun penuh, bergantung seberapa banyak hasil panen serta tersedianya gabah di area lokasi terebut dan para pelaku usaha masih banyak yang mengabaikan aspek manajerial terutama dalam hal pencatatan pembukuan, padahal kegiatan tersebut sangat bermanfaat untuk melihat apakah usaha itu layak dan menguntungkan. Sistem pembayaran jasa penggilingan padi di masing-masing tempat belum adanya penetapan jenis pembayaran standar yang sama antara para pelaku usaha. Secara umum pendapatan pelaku usaha penggilingan padi di dapat dari pembayaran yang dilihat dari seberapa banyak gabah yang di giling oleh petani, di samping itu pendapatan tambahan yang dapat diterima adalah dari penjualan sisa gabah halus (bekatul) yang dijual kepada konsumen untuk dijadikan sebagai pakan ternak akan tetapi dalam faktanya banyak petani yang menggiling lebih memilih membawa kembali bekatul hasil perontokan gabah dan membayar sukarela kepada pemilik penggilingan, secara ekonomis akan mengurangi pendapatan pelaku usaha penggilingan padi.

Untuk itu, peneliti tertarik untuk mengambil kajian penelitian tentang analisis kelayakan finansial dan tingkat sensitivitas usaha penggilingan padi di Kecamatan Lemahabang Kabupaten 
Cirebon guna memecahkan masalah berdasarkan latar belakang diatas.

\section{METODE PENELITIAN}

Objek dan lokasi penelitian ini adalah pelaku usaha penggilingan padi yang berlokasi di Kecamatan Lemahabang Kabupaten Cirebon Provinsi Jawa Barat. Lokasi penelitian ini dipilih secara sengaja (purposive) dengan pertimbangan bahwa terdapat usaha penggilingan padi dan daerah tersebut merupakan sentra produksi padi di Kabupaten Cirebon

Metode penelitian ini adalah penelitian survei yaitu metode penelitian kuantitatif yang digunakan untuk mendapatkan data yang terjadi pada masa lampau, atau saat ini tentang keyakinan, pendapat, karakteristik maupun perilaku (Sugiyono, 2013). Desain penelitian yang digunakan adalah penelitian kuantitatif deskriptif yaitu salah satu desain penelitian yang banyak digunakan pada penelitian yang bertujuan untuk menjelaskan suatu kejadian.

Populasi dalam penelitian ini yaitu pelaku usaha penggilingan padi yang berada di Kecamatan Lemahabang Kabupaten Cirebon. Penentuan responden dalam penelitian ini menggunakan metode nonprobability sampling adalah sampel terpilih atau purposive sampling. Di Kecamatan Lemahabang kabupaten Cirebon terdapat 15 usaha jasa Penggilingan Padi. Sampel yang diambil dalam penelitian menggunakan sensus yaitu semua usaha penggilingan padi yang berdiri kisaran tahun 2012 s.d 2014 yang didapat berjumlah 8 pelaku usaha /responden. Analisis data yang dilakukan dalam penelitian ini adalah sebagai berikut

\section{Biaya Produksi}

Menurut Soekartawi (1995), untuk mengetahui biaya total dapat dicari dengan menggunakan rumus sebagai berikut :

$$
\begin{array}{ll}
\text { TC } & =\text { FC + VC Dimana } \\
\text { TC } & =\text { Biaya total } \\
\text { FC } & =\text { Biaya Tetap } \\
\text { VC } & =\text { Biaya Variabel }
\end{array}
$$

\section{Penerimaan}

Rumus penerimaan dapat dicari dengan cara sebagai berikut :

TR $=$ Y. Py dimana :

$\mathrm{TR}=$ Total penerimaan

$\mathrm{Y} \quad=$ Produksi yang diperoleh dalam suatu usahatani

Py = Harga Y (Soekartawi, 1995)

\section{Pendapatan}

Untuk menganalisis pendapatan dapat diperoleh dengan rumus :

$\pi=T R-T C$

$\pi \quad=$ Keuntungan (profit)

$\mathrm{TR}=$ Penerimaan total

TC = Biaya total, yaitu semua biaya yang dikeluarkan untuk menghasilkan barang (Soeharno, 2009).

\section{Net Present Value (NPV)}

Rumus yang biasa digunakan dalam menghitung NPV adalah sebagai berikut :

$$
\begin{aligned}
& \mathrm{NPV}=\frac{\text { Kas bersih } 1}{(1+\mathrm{r})}+\frac{\text { Kas bersih } 2}{(1+\mathrm{r})^{2}} \\
&+ \frac{\text { Kas bersih } \mathrm{n}}{(1+\mathrm{r})^{\mathrm{n}}} \\
&- \text { Investasi }
\end{aligned}
$$

dimana :

$$
\begin{array}{ll}
\text { Investasi } & =\text { investasi } \\
\mathrm{r} & =\text { diskon rate } \\
\mathrm{n} & =\text { waktu }
\end{array}
$$

NPV positif, maka investasi diterima dan jika NPV negatif, sebaiknya investasi ditolak (Kasmir dkk., 2015). 


\section{Internal Rate Return (IRR)}

Internal Rate Return atau yang biasa di kenal IRR adalah merupakan discount rate yang dapat membuat besarnya NPV suatu proyek $=0$ atau dapat membuat $\mathrm{B} / \mathrm{C}$ ratio $=1$. Dalam perhitungan IRR diasumsikan bahwa setiap benefit ratio tahunan secara otomatis ditanam kembali dalam tahun dan memperoleh rate of return yang sama dengan investasi investasi sebelumnya

Untuk mencari IRR adalah dengan menggunakan rumus sebagai berikut :

$$
\mathrm{IRR}=\mathrm{i}_{1}+\frac{\mathrm{NPV} 1}{\mathrm{NPV} 1-\mathrm{NPV} 2} \times\left(\mathrm{i}_{2}-i_{1}\right)
$$

Dimana :

$\mathrm{i}_{1}=$ tingkat bunga 1 ( tingkat discount rate yang menghasilkan NPV 1 ).

$\mathrm{i}_{2}=$ tingkat bunga 2 ( tingkat discount rate yang menghasilkan NPV 2 ).

$\mathrm{NPV} 1=$ net present value 1

NPV $2=$ net present value 2

(Kasmir dkk., 2015).

\section{Net Benefit Cost Ratio (Net B/C Ratio)}

Net benefit cost ratio merupakan perbandingan antara net benefit yang telah di discont positif (+) dengan net benefit yang telah di discont negatif (-) dengan formula sebagai berikut :

Net $\mathrm{B} / \mathrm{C}=\frac{\sum_{\mathrm{i}=1}^{\mathrm{n}} \mathrm{NB}_{\mathrm{i}} \quad(+)}{\sum_{\mathrm{i}=1}^{\mathrm{n}} \mathrm{N}_{\mathrm{B}} \quad(-)}$

Jika nilai Net B/C lebih besar dari 1 (satu) berarti gagasan usaha / proyek tersebut layak untuk dikerjakan dan jika lebih kecil dari (1) satu berarti cash in flows sama dengan cash out flows, dalam present value disebut dengan break event point (BEP), yaitu total cost sama dengan total revenue (Ibrahim, 2003).

\section{ARR (Average Rate of Return)}

Untuk mencari ARR dapat menggunakan rumus :

$$
\begin{aligned}
& \mathrm{ARR}= \\
& \frac{\text { Rata-rata EAT (average earning after tax) }}{\text { Rata-rata investasi (average nvestment) }} \mathrm{X} \\
& 100 \% \\
& \text { Rata }- \text { rata EAT }=\frac{\text { Total EAT }}{\text { Umur ekonomis }} \\
& \text { Rata - rata investasi }=\frac{\text { Investasi }}{2}
\end{aligned}
$$

(Kasmir, 2003).

Jika ARR lebih besar (>) dari tingkat keuntungan yang disyaratkan berarti investasi layak dilakukan dan menguntungkan, sebaliknya jika ARR lebih kecil $(<)$ dari tingkat keuntungan yang disyaratkan maka investasi tidak layak dilakukan. Asumsi yang digunakan untuk tingkat pengembalian / keuntungan yang di inginkan selama periode usaha penggilingan padi adalah sebesar 50\%.

\section{Payback Period}

Menurut Ibrahim (2003), rumus payback periode dapat dicari dengan menggunakan cara sebagai berikut :

$$
\begin{aligned}
& \mathrm{PBP}=\mathrm{T}_{\mathrm{p}-1}+\frac{\sum_{\mathrm{i}=1}^{\mathrm{n}} \mathrm{I}_{\mathrm{i}}-\sum_{\mathrm{i}=1}^{\mathrm{n}} \mathrm{B}_{\mathrm{icp}-1}}{\mathrm{~B}_{\mathrm{p}}} \\
& \text { PBP = Payback period } \\
& \mathrm{T}_{\mathrm{p}-\mathrm{i}} \quad=\text { Tahun sebelum terdapat PBP } \\
& \mathrm{I}_{\mathrm{i}} \quad=\text { Jumlah Investasi yang telah di } \\
& \text { discount }
\end{aligned}
$$

- Periode pengembalian lebih cepat : layak

- Periode pengembalian lebih lama : tidak layak.

\section{Analisis Sensitivitas}

Analisis sensitivitas merupakan suatu analisis kembali untuk melihat pengaruh-pengaruh yang akan terjadi 
sebagai akibat dari keadaan yang berubah. Hal-hal yang terkait pada perubahan tersebut dipengaruhi beberapa variabel diantaranya harga, kenaikan biaya dan hasil produksi.

Dalam penelitian ini, variabel yang dianalisis sensitivitasnya adalah :

a. Penurunan jumlah giling sebesar 10 $\%$ diambil dari data penurunan jumlah hasil produksi padi 2 tahun terakhir di Kecamatan Lemahabang.

b. Kenaikan harga bahan baku solar sebesar $5,3 \%$ dari data rata-rata inflasi 5 tahun terakhir.

Menurut Gittinger dalam (Kadariah \& Clive, 2001), Untuk mengukur laju kepekan dapat dihitung dengan rumus :

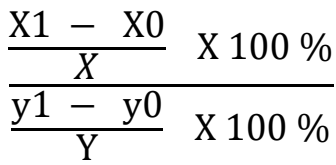

$\mathrm{X} 1=\mathrm{NPV} / \mathrm{IRR} / \mathrm{Net} \mathrm{B} / \mathrm{C}$ ratio setelah terjadi perubahan.

$\mathrm{X} 0=\mathrm{NPV} / \mathrm{IRR} / \mathrm{Net} \mathrm{B} / \mathrm{C}$ ratio sebelum terjadi perubahan.

$\overline{\mathrm{X}}=$ Rata - rata Perubahan NPV/IRR/Net BC ratio

Y1 = Biaya produksi/harga jual/hasil produksi setelah perubahan

Y0 = Biaya produksi/harga jual/hasil produksi sebelum perubahan

$\overline{\mathrm{Y}}=$ Rata - rata perubahan biaya produksi/harga jual/hasil produksi

Kriteria pengambilan keputusan untuk laju kepekaan adalah :

a. Jika laju kepekaan > 1, maka hasil usaha peka atau sensitif terhadap perubahan. Jika laju kepekaan < 1 , maka hasil usaha tidak peka atau tidak sensitif terhadap perubahan. b. Usaha dikatakan tidak sensitif terhadap perubahan apabila $\mathrm{LK}<1$.

\section{HASIL DAN PEMBAHASAN}

Lemahabang adalah sebuah Kecamatan di Kabupaten Cirebon, Secara geografis Kecamatan Lemahabang terletak pada titik kordinat 108 o 40 - 108 o 48 bujur timur dan 06o 30 - 07o 00 lintang selatan. Kecamatan Lemahabang memiliki luas wilayah sekitar 21,49 $\mathrm{Km} 2$ atau seluas 2.149 Ha, Kecamatan Lemahabang merupakan daerah dataran rendah dengan ketinggian rata-rata 40 meter diatas permukaan laut, dengan suhu pada umumnya panas dan sedang yang dipengaruhi oleh iklim musim kemarau dan penghujan.

\section{Karakteristik Responden Berdasarkan Jenis Pengilingan Padi dan Kapasitas Mesin}

Secara umum pelaku usaha penggilingan padi yang diteliti di Kecamatan Lemahabang Kabupaten Secara umum pelaku usaha penggilingan padi di Kecamatan Lemahabang Kabupaten Cirebon berjenis usaha penggilingan padi rakyat dengan kapasitas maksimal mesin produksi $700 \mathrm{Kg} / \mathrm{Jam}$, akan tetapi jam kerja para pelaku usaha penggilingan padi tidak menentu dan kebanyakan mereka membuka usahanya sekitar 4 s.d 6 jam perhari. Hal ini menunjukkan bahwa pelaku usaha penggilingan padi di Kecamatan Lemahabang berjenis penggilingan padi rakyat dan menggunakan tipe mesin penggilingan padi sederhana. Penggilingan padi sederhana umumnya mendapatkan gabah giling dari para petani 
sekitar, belum mampu bersaing dengan pelaku usaha penggilingan padi berjenis besar karena keterbatasan mesin maupun modal. Menurut Patiwiri (2006), Penggilingan padi sederhana adalah unit peralatan teknik yang berfungsi sebagai mesin pengolah gabah menjadi beras, baik merupakan satu unit tersendiri maupun merupakan gabungan dari beberapa mesin, di mana proses satu dengan yang lain dihubungkan oleh proses pemindahan bahan dengan menggunakan tenaga manusia.

\section{Investasi dan Penyusutan}

Biaya investasi dikeluarkan pada saat pelaku usaha akan menjalankan usahanya, dengan tujuan dengan dilakukanya sebuah investasi dalam sebuah usaha akan memberikan keuntungan dalam periode waktu yang akan datang yakni selama umur usaha atau selama usaha itu akan dijalankan. Untuk rata-rata biaya investasi terdapat pada Tabel 2.

Tabel 2. Rata-rata Biaya Investasi Usaha Penggilingan Padi

\begin{tabular}{rlcrrr}
\hline No & Komponen Biaya & Satuan & Jumlah & Harga Satuan & Jumlah Biaya \\
\hline 1 & Perizinan & Paket & 1 & 5.250 .000 & 5.250 .000 \\
2 & Bangunan & $\mathrm{m}^{2}$ & 1 & 47.500 .000 & 47.500 .000 \\
3 & Tanah & $\mathrm{m}^{2}$ & 1 & 29.503 .125 & 29.503 .125 \\
4 & Kendaraan & Unit & 1 & 70.000 .000 & 8.750 .000 \\
& b. Pick Up & Unit & 1 & 10.250 .000 & 10.250 .000 \\
& c. Sepeda Motor & & & & \\
5 & Mesin & Unit & 1 & 8.312 .500 & 8.312 .500 \\
& a. Husker & Unit & 1 & 7.500 .000 & 7.500 .000 \\
& b. Polisher & Unit & 1 & 7.250 .000 & 7.250 .000 \\
& c. Diesel & Unit & 1 & 3.612 .500 & 3.612 .500 \\
& d. Ayakan & Unit & 1 & 443.750 & 443.750 \\
e. Mesin jahit & & & & \\
6eralatan lainnya & Unit & 1 & 2.125 .000 & 2.125 .000 \\
& a. Timbangan Besar & Unit & 1 & 400.000 & 400.000 \\
b. Timbangan Kecil & Unit & 13 & 19.375 & 254.375 \\
& c. Ember/Bakul & Unit & 1 & 71.875 & 81.250 \\
d. Skop & & & & 131.232 .500 \\
\hline
\end{tabular}

Berdasarkan Tabel 2 dapat dijelaskan bahwa rata-rata total biaya investasi yang dikeluarkan pelaku usaha penggilingan padi di Kecamatan Lemahabang adalah Rp 131.232.500 yang terdiri dari biaya perizinan, pembuatan gedung, tanah, kendaraan, pembelian mesin-mesin dan perlengkapan seperti skop, ember, timbangan besar dan kecil. dan dapat kita lihat juga bahwa biaya investasi yang dikeluarkan paling besar untuk pembuatan bangunan sebesar Rp 47.500.000. 
Berdasarkan Tabel 3 dapat yakni Rp 3.218 .750 dalam satu tahun. dijelaskan bahwa besarnya nilai biaya Untuk mengetahui lebih jelasnya, rata-rata penyusutan usaha penggilingan padi biaya penyusutan pada usaha penggilingan Kecamatan Lemahabang rata-rata sebesar Rp 9.472.705 dengan biaya penyusutan padi di Kecamatan Lemahabang dapat dilihat dan tersaji pada Tabel 3 di bawah terbesar dikeluarkan untuk biaya bangunan ini.

Tabel 3.Rata - Rata Biaya Penyusutan Usaha Penggilingan Padi

\begin{tabular}{clcr}
\hline No & Komponen Biaya & Umur Ekonomis (tahun) & Nilai Penyusutan (Rp) \\
\hline 1 & Perizinan & 15 & 3.218 .750 \\
3 & Tanah & & \\
4 & Kendaraan & 10 & \\
& a. Pick Up & 8 & 875.000 \\
& b. Sepeda Motor & & 1.319 .196 \\
5 & Mesin & 8 & \\
& a.Husker & 8 & 1.039 .063 \\
& b.Polisher & 8 & 937.500 \\
& c.Diesel & 5 & 906.250 \\
& d.Mesin Jahit & 7 & 88.750 \\
& e.Ayakan & & 516.071 \\
6 & Peralatan lainnya & & \\
& a.Timbangan Besar & 5 & 425.000 \\
& b.Timbangan Kecil & 5 & 80.000 \\
& c.Ember & 5 & 50.875 \\
& d.Skop & 5 & 16.250 \\
\hline & Jumlah & & 9.472 .705 \\
\hline
\end{tabular}

\section{Penerimaan}

Penerimaan adalah hasil dari jumlah produksi dikalikan dengan harga yang berlaku saat itu. Usaha penggilingan padi di Kecamatan Lemahabang Kabupaten Cirebon rata-rata memproduksi tiga jenis barang/jasa yaitu jasa giling/ongkos giling rata-rata harga sebesar Rp 200 s.d 300/Kg, penjualan beras ratarata harga antara Rp 8.500 s.d $10.000 / \mathrm{Kg}$ dan penjualan bekatul antara harga $\mathrm{Rp}$ 2000 s.d 3000/Kg,

Berdasarkan Tabel 5 dapat dijelaskan bahwa rata-rata penerimaan usaha penggilingan padi tertinggi terjadi pada tahun 2014 sebesar Rp 299.206.500 sedangkan penerimaan tekecil rata-rata pelaku usaha penggilingan padi terjadi pada tahun 2016 sebesar Rp 253.193.500, lebih jelasnya untuk melihat penerimaan usaha penggilingan padi di Kecamatan Lemahabang dapat dilihat rata - ratanya yang tersaji pada tabel 5 dibawah ini. Besar kecilnya pendapatan suatu usaha tergantung seberapa banyak output produksi yang dihasilkan dan harga yang berlaku pada waktu saat diperhitungkan, dalam penelitian ini yakni dari penjualan beras, volume jumlah giling dan penerimaan dari penjualan bekatul. 
Tabel 5. Rata - Rata Penerimaan Usaha Penggilingan Padi

\begin{tabular}{lccccr}
\hline & \multicolumn{5}{c}{ Tahun } \\
\cline { 2 - 6 } Penerimaan & \multicolumn{7}{c}{2013} & 2014 & 2015 & 2016 & 2017 \\
& $\mathrm{Rp} / 000$ & $\mathrm{Rp} / 000$ & $\mathrm{Rp} / 000$ & $\mathrm{Rp} / 000$ & $\mathrm{Rp} / 000$ \\
\hline Jasa Giling & $17.160,0$ & $17.160,0$ & $18.231,2$ & $17.745,0$ & $17.745,0$ \\
Pen. Beras & $241.718,7$ & $253.012,5$ & $245.025,0$ & $209.807,5$ & $215.000,0$ \\
Pen. Bekatul & $29.034,0$ & $29.034,0$ & $28.644,0$ & $25.641,0$ & $25.382,0$ \\
\hline Jumlah & $287.912,7$ & $299.206,5$ & $291.900,2$ & $253.193,5$ & $259.127,0$ \\
\hline
\end{tabular}

Sumber : Data primer

\section{Penerimaan dari Nilai Sisa}

Penerimaan terakhir rata-rata pada tahun terakhir penaksiran umur pelaku penggilingan padi adalah dari nilai sisa dari barang-barang investasi. jelasnya rata-ratanya dapat dilihat pada Penerimaan untuk nilai sisa ini diperoleh Tabel6.

Tabel 6. Rata-Rata Nilai Sisa Usaha Penggilingan Padi

\begin{tabular}{|c|c|c|c|}
\hline No & Komponen Biaya & Umur Ekonomis (tahun) & Nilai Sisa (Rp) \\
\hline 1 & Perizinan & & \\
\hline 2 & Bangunan & 15 & 31.406 .250 \\
\hline 3 & Tanah & & 28.975 .000 \\
\hline \multirow[t]{3}{*}{4} & Kendaraan & & \\
\hline & a. Pick Up & 10 & 4.375 .000 \\
\hline & b. Sepeda Motor & 8 & 3.654 .018 \\
\hline \multirow[t]{6}{*}{5} & Mesin & & \\
\hline & a.Husker & 8 & 3.117 .188 \\
\hline & b.Polisher & 8 & 2.812 .500 \\
\hline & c.Diesel & 8 & 2.718 .750 \\
\hline & d.Mesin Jahit & 5 & \\
\hline & e.Ayakan & 7 & 1.032 .143 \\
\hline \multirow[t]{6}{*}{6} & Peralatan lainnya & & \\
\hline & a.Timbangan Besar & 5 & \\
\hline & b.Timbangan Kecil & 5 & \\
\hline & c.Ember & 5 & \\
\hline & d.Skop & 5 & \\
\hline & Jumlah & & 78.090 .848 \\
\hline
\end{tabular}

Berdasarkan Tabel 6 dapat rata - rata sebesar Rp 28.975.000. Hal ini dijelaskan bahwa nilai sisa investasi dalam dikarenakan harga tanah setiap tahun usaha penggilingan padi di Kecamatan harganya cenderung tetap dan bahkan Lemahabang ditaksir rata-rata sebesar Rp selalu mengalami peningkatan karena 78.090.848 dengan nilai sisa tertinggi tanah tidak mengalami penyusutan, nilai berasal dari investasi berupa tanah dengan sisa diperoleh dari barang investasi yang 
masih memiliki nilai di akhir tahun perhitungan.

\section{Pendapatan Usaha Penggilingan Jasa}

Padi

Pendapatan merupakan selisih antara penerimaan dan biaya-biaya yang dikeluarkan dalam kegiatan usaha dalam jangka waktu tertentu. Untuk melihat pendapatan usaha penggilingan padi dapat dilihat rata pendapatan tersaji dalam tabel

7. Berdasarkan Tabel 7 dapat dijelaskan bahwa pendapatan tertinggi rata-rata pengusaha penggilingan padi di Kecamatan Lemahabang terjadi di tahun 2017 yakni sebesar Rp.41.463.759, hal ini dikarenakan jumlah produksi yang tinggi dibarengi dengan biaya dan harga penjualan beras yang sesuai diharapkan. Sedangkan pendapatan terendah rata - rata terjadi pada tahun 2016 yakni sebesar Rp 33.289.012 faktornya adalah selain meningkatnya kepercayaan petani terhadap tengkulak, pada tahun tersebut harga bahan bakar naik signifikan dan hasil panen padi di masyarakat setiap tahun mengalami penurunan karena alih fungsi lahan dan faktor-faktor lainya.

Tabel 7. Rata - rata Pendapatan Usaha Penggilingan Padi

\begin{tabular}{lccccr}
\hline Komponen & 2013 & 2014 & 2015 & 2016 & \multicolumn{2}{c}{$\begin{array}{c}2017 \\
\mathrm{Rp} / 000\end{array}$} \\
& $\mathrm{Rp} / 000$ & $\mathrm{Rp} / 000$ & $\mathrm{Rp} / 000$ & $\mathrm{Rp} / 000$ & $259.127,0$ \\
\hline Peneriman & $287.912,7$ & $299.206,5$ & $291.900,2$ & $253.193,5$ & $217.663,2$ \\
Biaya total & $249.784,7$ & $257.878,5$ & $257.101,8$ & $219.904,5$ & $41.463,8$ \\
\hline Pendapatan & $38.128,0$ & $41.328,0$ & $34.798,4$ & $33.289,0$ & \\
\hline
\end{tabular}

Sumber : Data primer.

\section{Analisis Kelayakan Finansial}

Analisis kelayakan finansial digunakan untuk mengetahui perbandingan jumlah biaya yang dikeluarkan dengan penerimaan yang di dapat dari suatu proses produksi apakah suatu proses produksi tersebut layak untuk diusahakan dan dapat memberikan keuntungan. Hasil analisis kelayakan finansial pada usaha penggilingan padi di Kecamatan Lemahabang Kabupaten Cirebon dapat dilihat pada rata-ratanya yang tersaji dalam Tabel 8.

Tabel 8. Rata - rata Hasil Analisis Kelayakan Finansial Usaha Penggilingan Padi Pada Tingkat Suku Bunga 17\% (df = 17\%).

\begin{tabular}{lll}
\hline Analisis Kelayakan Finansial & & \\
\hline Kriteria & Nilai & Keterangan \\
NPV (Net Present Value) & 24.683 .347 & Layak \\
IRR (Internal Rate of Return ) & $24 \%$ & Layak \\
Net B/C rasio & 1,20 & Layak \\
ARR (Average Rate of Return ) & $59 \%$ & Layak \\
Payback periode & 3,77 & Layak \\
\hline
\end{tabular}


Tabel 8 menunjukkan besarnya nilai NPV rata-rata usaha penggilingan padi di Kecamatan Lemahabang pada tingkat suku bunga 17\% adalah Rp.24.693.347 yang berarti nilai NPV tersebut bernilai postif atau lebih dari nol. Besarnya nilai IRR pada tingkat suku buga $17 \%$ untuk rata-rata usaha penggilingan padi di Kecamatan Lemahabang adalah $24 \%$, yang berarti nilai IRR lebih besar dari tingkat suku bunga yang digunakan. Hasil perhitungan Net $\mathrm{B} / \mathrm{C}$ rasio rata-rata pelaku usaha penggilingan padi pada tingkat suku bunga $17 \%$ adalah sebesar 1,20. Hasil perhitungan ARR didapat sebesar 59\%. Artinya rata-rata usaha penggilingan padi di Kecamatan Lemahabang Kabupaten Cirebon dilihat dari kemampuan pengembalian bunga dapat dikatakan layak karena hasil dari ARR lebih besar dari tingkat pengembalian bunga yang disyaratkan yaitu 50\%. Tabel 8 menjelaskan bahwa hasil perhitungan didapat payback periode selama 3 tahun 7 bulan 7 hari.

\section{Analisis Sensitivitas}

Analisis senstivitas merupakan sutu kegiatan menganalisis kembali suatu usaha. Analisis sensitivitas digunakan untuk mengetahui perubahan faktor-faktor dalam dan luar yang dapat mempengaruhi nilai penerimaan dan biaya dalam suatu usaha terhadap kriteria investasi seperti NPV, Net B/C Ratio, IRR, PP, ARR dan Payback periode. Perubahan faktor yang dapat mempengaruhi penerimaan dan biaya dalam suatu usaha biasanya seperti kenaikan harga bahan baku, penurunan jumlah produksi dan penurunan harga jual.

Dalam penelitian ini faktor yang diambil yaitu penurunan jumlah giling sebesar $10 \%$ dilihat dari selisih penurunan produksi 2 tahun terakhir dan kenaikan harga solar sebesar 5,3\% yang didasari dari nilai rata-rata invlasi dalam 5 tahun terakhir yang diasumsikan akan menaikkan harga input yang dipakai.

\section{Penurunan Jumlah Giling $10 \%$}

Analisis sensitivitas terhadap penurunan jumlah giling sebesar $10 \%$. Penurunan jumlah giling bisa terjadi dan dapat disebabkan dari berbagai faktor terutama ketersediaan gabah kering giling (GKG) di daerah penelitian. Hasil perhitunganya dapat dilihat pada rataratanya yang tersaji pada Tabel 9

Tabel 9. Rata - rata Hasil Analisis Sensitivitas Penurunan Jumlah Giling Sebesar $10 \%$

\begin{tabular}{lrrl}
\hline Kriteria & \multicolumn{1}{c}{ Nilai Awal } & Nilai Akhir & Keterangan \\
\hline NPV & 24.693 .347 & 868.736 & Layak \\
IRR & $24 \%$ & $18 \%$ & Layak \\
Net B/C rasio & 1,20 & 1,02 & Layak \\
ARR & $59 \%$ & $46 \%$ & Tidak Layak \\
Payback periode & 3,77 & 4,42 & Layak \\
\hline
\end{tabular}

Berdasarkan Tabel 9 dapat dijelaskan bahwa penurunan jumlah giling sebesar $10 \%$ menyebabkan seluruh kriteria analisis mengalami penurunan nilai, hal ini 
menandakan jika terjadi penurunan jumlah giling sebesar $10 \%$, maka rata - rata pelaku usaha penggilingan padi di Kecamatan Lemahabang Kabupaten Cirebon kecewa dan akan mengalami penurunan pendapatan yang cukup signifikan. Akibat dari penurunan variabel tersebut, berdampak pada kriteria investasi yang digunakan sehingga usaha penggilingan padi di Kecamatan Lemahabang menjadi rawan, karena secara umum nilai yang dihasilkan mendekati batas penilaian dari kriteria investasi yang digunakan kecuali hasil dari nilai ARR yang berubah menjadi tidak layak

\section{Kenaikan Harga Solar 5,3 \%}

Analisis terhadap kenaikan harga solar sebesar 5,3\% didasarkan pada ratarata nilai inflasi dari tahun 2013 s.d 2017 , diasumsikan bahwa suatu waktu harga solar naik dikarenakan pengaruh dari inflasi. Hasil perhitungan rata-ratanya tersaji dalam Tabel 10.

Tabel 10. Rata - rata Hasil Analisis Sensitivitas Kenaikan Harga Bahan Baku Solar 5,3 \%

\begin{tabular}{|c|c|c|c|}
\hline Kriteria & Nilai Awal & Nilai Akhir & Keterangan \\
\hline NPV & 24.693 .347 & 21.279 .349 & Layak \\
\hline IRR & $24 \%$ & $24 \%$ & Layak \\
\hline Net $B / C$ rasio & 1,20 & 1,17 & Layak \\
\hline ARR & $59 \%$ & $59 \%$ & Layak \\
\hline Payback periode & 3,77 & 3,78 & Layak \\
\hline
\end{tabular}

Sumber : Data primer

Berdasarkan Tabel 10 dapat dijelaskan bahwa kenaikan harga solar sebesar 5,3\% menyebabkan seluruh nilai dari kriteria yang digunakan menurun akan tetapi tidak terlalu signifikan. Walaupun terjadi penurunan kriteria, usaha penggilingan padi di Kecamatan Lemahabang Kabupaten Cirebon masih dikatakan layak diusahakan karena secara umum nilai kriteria yang digunakan, masing - masing masih lebih besar dari batas kriteria kelayakan. Hasil ini selaras dengan penelitian Krisbiyantoro (2016) yang mengungkapkan bahwa pada saat kenaikan harga solar 5,3\% dan diikuti dengan kenaikan upah tenaga kerjamaka masih dikatakan layak karena seluruh kriteria masih positif atau diatas kriteria.Analisis Sensitivitas sangat penting dilakukan untuk mengantisipasi segala ketidakpastian yang akan dihadapi. Menurut Umar (2003), bahwa ketidakpastian itu dapat menyebabkan berkurangnya kemampuan suatu proyek bisnis dalam beroperasi untuk menghasilkan laba bagi perusahaan.

\section{Laju Kepekaan Analisis Sensitivitas}

Laju kepekaan dihitung dari hasil perhitungan analisis sensitivitas yang bertujuan untuk menentukan apakah usaha penggilingan padi yang dijalankan di Kecamatan Lemahabang Kabupaten Cirebon peka atau sensitif terhadap segala perubahan yang terjadi. Berdasarkan Tabel 21 hasil laju kepekaan dari penurunan jumlah giling sebesar $10 \%$ secara keseluruhan nilainya $>0$ yang artinya penurunan jumlah giling sebesar $10 \%$ peka terhadap usaha penggilingan padi, dapat dijelaskan bahwa usaha penggilingan padi sensitif terhadap penurunan jumlah giling 
sebesar $10 \%$ karena memengaruhi nilai NPV, IRR, Net B/C Ratio, ARR dan Payback Peiode dengan nilai laju kepekaan tertinggi yaitu nilai IRR sebesar 4,53. Untuk lebih jelasnya hasil analisis sensitivitas dilihat dari kepekanya dapat dilihat pada rata - ratanya yang tersaji pada Tabel 11.

Tabel 11. Rata - rata Hasil Laju Kepekaan Analisis Sensitivitas Usaha Penggilingan Padi Dengan Tingkat Suku Bunga $17 \%$

\begin{tabular}{|c|c|c|c|c|c|}
\hline No & Kriteria & $\begin{array}{l}\text { Sebelum } \\
\text { Perubahan }\end{array}$ & $\begin{array}{c}\text { Sesudah } \\
\text { Perubahan }\end{array}$ & Laju Kepekaan & Ket \\
\hline 1. & $\begin{array}{l}\text { Penurunan jumlah giling } 10 \% \\
\text { a. NPV (Rp) }\end{array}$ & 24.693 .347 & 868.736 & $-2,26$ & S \\
\hline & b. IRR $(\%)$ & $24 \%$ & $18 \%$ & 4,53 & S \\
\hline & c. Net B/C Ratio & 1,20 & 1,02 & 1,59 & S \\
\hline & d. $\operatorname{ARR}(\%)$ & $59 \%$ & $46 \%$ & 2,53 & S \\
\hline & e. Payback periode & 3,77 & 4,42 & $-1,60$ & S \\
\hline 2. & Kenaikan harga solar 5,3\% & & & & \\
\hline & a. NPV (Rp) & 24.693 .347 & 24.168 .424 & 0,010 & TS \\
\hline & b. IRR $(\%)$ & $24 \%$ & $24 \%$ & 0,012 & TS \\
\hline & c. Net B/C Ratio & 1,20 & 1,17 & 0,006 & TS \\
\hline & d. ARR $(\%)$ & $59 \%$ & $59 \%$ & 0,004 & TS \\
\hline & e. Payback periode & 3,77 & 3,78 & 0,079 & TS \\
\hline
\end{tabular}

Keterangan : $\mathrm{S}=$ Sensitif TS $=$ Tidak Sensitif

Selanjutnya pengaruh dari kenaikan harga bahan baku solar sebesar $5,3 \%$ secara umum tidak mempengaruhi nilai analisis kriteria usaha penggilingan padi dikarenakan secara keseluruhan nilai laju kepekaan < 0 yaitu NPV sebesar 0,010, IRR 0,012, Net B/C Ratio 0,006, ARR 0,004 dan Payback periode 0,079. Dengan terjadinya kenaikan harga solar sebesar 5,3 $\%$ tidak terlalu berdampak bagi rata - rata pelaku usaha penggilingan padi di Kecamatan Lemahabang Kabupaten Cirebon.

Hasil analisis sensitivitas tersebut menjelaskan bahwa penurunan jumlah giling $10 \%$ berpengaruh terhadap kelayakan, sedangkan kenaikan harga solar sebesar $5,3 \%$ tidak mempengaruhi kelayakan rata-rata usaha penggilingan padi di Kecamatan Lemahabang Kabupaten Cirebon. Penurunan jumlah giling cukup berdampak pada penurunan pendapatan pelaku usaha karena bahan baku utama dari usaha penggilingan padi adalah gabah kering giling (GKG) dari petani. Apabila stok padi petani sekitar melimpah, ini sangat menguntungkan bagi usaha penggilingan padi. Hasil penelitian ini sesuai dengan penelitian Wildayana (2016) yang mengungkapkan bahwa faktor yang lebih sensitif terhadap usaha penggilingan padi (RMU) adalah penurunan jumlah giling tahunan.

\section{Sensitivitas Penurunan Jumlah Giling Pada Tingkat Penurunan 5\%, Tingkat Penurunan $10 \%$ dan Tingkat Penurunan $15 \%$.}

Berdasarkan hasil perhitungan tingkat kepekaan, bahwa penurunan jumlah giling peka bagi usaha 
penggilingan padi di Kecamatan Lemahabang Kabupaten Cirebon, maka perlu diketahui pada tingkat berapa persen akan mengakibatkan pelaku penggilingan merugi. Untuk melihat pada tingkat berapa persen penurunan jumlah giling, dilakukan estimasi penurunan dari tingkat penurunan $5 \%$ s.d $15 \%$ yang hasilnya dapat dilihat pada hasil rata-rata perbandingan penurunan jumlah giling pada tingkat penurunan $5 \%$ s.d $15 \%$ yang tersaji dalam table 12 .

Tabel 12. Sensitivitas Penurunan Jumlah Giling pada Tingkat Penurunan 5\%, $10 \%$ dan $15 \%$.

\begin{tabular}{lrrr}
\hline \multicolumn{1}{c}{ Analisis Finansial } & $5 \%$ & $10 \%$ & $15 \%$ \\
\hline NPV (Net Present Value ) & 16.952 .287 & 868.736 & -12.851 .826 \\
IRR ( Internal Rate of Return) & $22 \%$ & $18 \%$ & $13 \%$ \\
Net B/C Ratio & 1,14 & 1,13 & 0,89 \\
ARR ( Average Rate of Return) & $55 \%$ & $52 \%$ & $41 \%$ \\
Payback Periode & 4,00 & 4,42 & 5,12 \\
\hline
\end{tabular}

Sumber: Data Primer

Berdasarkan Tabel 12 dapat dijelaskan bahwa tingkat sensitivitas penurunan jumlah giling sebesar 10\% akan berdampak pada penurunan seluruh keriteria kelayakan akan tetapi masih dalam kondisi menguntungkan walau tidak signifikan, dan pada saat terjadi penurunan jumlah giling sebesar $15 \%$ seluruh kriteria kelayakan dibawah batas kelayakan, ini berarti dalam perhitungan lima tahun usaha berjalan, rata-rata pelaku usaha penggilingan padi di Kecamatan Lemahabang Kabupaten Cirebon akan mengalami kerugian.

Hasil penelitian ini sesuai dengan hasil penelitian Krisbiyantoro (2016) yang mengungkapkan bahwa pada saat penurunan jumlah giling mencapai $15 \%$ usaha penggilingan padi masih layak dengan discont rate $12 \%$, dan pada saat penurunan jumlah giling $30 \%$ s.d $45 \%$ usaha penggilingan padi menjadi tiak layak, hal ini dapat dilihat dari hasil NPV, IRR dan B/C Ratio yang tidak memenuhi syarat kelayakan. Menurut Wildayana (2016) bahwa faktor yang lebih sensitif terhadap usaha penggilingan padi (RMU) adalah penurunan jumlah giling tahunan.

\section{KESIMPULAN}

Berdasarkan hasil penelitian tentang analisis kelayakan finansial dan sensitivitas usaha penggilingan padi di Kecamatan Lemahabang Kabupaten Cirebon dapat disimpulkan sebagai berikut

1. Hasil analisis finansial dengan menggunakan kriteria kelayakan investasi yaitu NPV, IRR, Net B/C Ratio, ARR dan Payback Periode menunjukkan bahwa rata - rata usaha penggilingan padi di Kecamatan Lemahabang Kabupaten Cirebon layak untuk dijalankan dalam perhitungan umur 5 tahun dengan diskon rate sebesar $17 \%$ yang mampu menghasilkan nilai NPV (Net Present Value) sebesar Rp.24.693.347, IRR (Internal Rate of Return) sebesar 24\%, Net B/C Ratio sebesar 1,20, ARR (Average Rate of Return) sebesar 59\% 
dan Payback Period selama 3 tahun 7 bulan 7 hari.

2. Untuk hasil analisis sensitivitas dengan penurunan jumlah giling sebesar $10 \%$ akan mengakibatkan rata-rata pelaku usaha penggilingan padi masih layak akan tetapi rawan karena mendekati batas nilai kelayakan dan pada saat penurunan jumlah giling sebesar $15 \%$ rata-rata usaha penggilingan padi menjadi tidak layak. Untuk analisis sensitivitas pada saat kenaikan harga solar $5,3 \%$, bagi rata-rata pelaku usaha penggilingan padi di Kecamatan Lemahabang Kabupaten Cirebon masih layak untuk dijalankan.

\section{DAFTAR PUSTAKA}

Ibrahim, H. M. Y. (2003). Studi kelayakan bisnis. PT Rineka Cipta.

Kadariah, K. L., \& Clive, G. (2001). Evaluasi Proyek Analisis Ekonomis. Edisi kedua. Fakultas Ekonomi Universitas Indonesia. Jakarta.

Kasmir, J. (2003). Studi Kelayakan Bisnis. Jakarta: Prenada Media.

Kasmir, S. E., \& others. (2015). Studi Kelayakan Bisnis: Edisi Revisi. Prenada Media.
Krisbiyantoro, J. (2016). Analisis Biaya dan Kelayakan Usaha Penggilingan Padi Tipe Single Passdi Desa Teluk Pandan Kecamatan Teluk Pandan. Jurnal Pertanian Terpadu, 4(2), 6180.

Nuryati, L., Waryanto, B., \& Noviati, R. W. (2015). Outlook Komoditas Pertanian Tanaman Pangan Padi. Pusat Data Dan Sistem Informasi Pertanian Kementerian Pertanian, Indonesia.

Patiwiri, A. W. (2006). Teknologi penggilingan padi. PT Gramedia Pustaka Utama. Jakarta.

Soeharno, P. D. (2009). Teori Ekonomi Mikro. Yogyakarta: $C V$ ANDI OFFSET.

Soekartawi. (1995). Analisis Usahatani. Universitas Indonesia.

Sugiyono, P. D. (2013). Metode penelitian manajemen. Bandung: Alfabeta, $C V$.

Umar, H. (2003). Studi kelayakan bisnis Edisi 2. PT. Gramedia Pustaka Utama. Jakarta.

Wildayana, E. (2016). Kelayakan Finansial Usaha Penggilingan Padi di Kecamatan Tanjung Lago Banyuasin Sumatera Selatan. HABITAT, 26(2), 130-135. 